\title{
Dibya Upadesh: Pragmatic Guidelines to Nepalese Diplomacy
}

\author{
Lecturer, Bhim Nath Baral, PhD Scholar \\ Department of Political Science, Tribhuvan University, Prithvi \\ Narayan Campus, Pokhara, Nepal
}

\begin{abstract}
The origin of Nepal's foreign policy dates back to the time of unification of Nepal by king Prithvi Narayan Shah in 1769. For the first time, Nepal was able to make structural provision to conduct foreign policy in a more successful way by deputing skilled officers. It was king Prithvi Narayan Shah who displayed skillful diplomacy in the initiation and successful operation of very challenging task of unification. Credit goes to his skillful war diplomacy. Besides spending active life from The House of Gorkha, he also became an ideal guardian to his successors. Keeping in view, the survival of the nation, he delivered some pragmatic instructions as an oratory to his courtiers and royal priests which we refer to as Dibya Upadesh. It covers the political, economic, strategic, military, geographical and other sectors of national life. More attention is given towards the protection of sovereignty and integrity of the country. So, this paper aims to analyze diplomatic insights expressed through Dibya Upadesh in domestic and external matter by taking state's survival into consideration. The article is descriptive and analytical and data are acquired from secondary sources.
\end{abstract}

Keywords: Instruction, sovereignty, strategy, successors, survival, unification.

\section{Introduction}

Nepal has never remained under the colony of any world power but it passed through a challenging mode during its early days of nation-building. Nepal's unique geographical location 
between two Asian giants-China and India-always knocks Nepal in every matter of domestic and foreign concern. Historically, Nepal being a country with rich historical and long glorious past, is one of the oldest states having 5000 near long history (Dahal,2018:82-113). This proves that Nepal has a long and glorious history of nation building. It was only seven years after the beginning of modern Nepal, USA, the present- day global power, became independent from British colonial rule in 1776. However, the second-half of 18th century witnessed that the brave, visionary and nationalist king Prithvi Narayan Shah provided modern Nepal's foreign and security policies along with shaping its world view (Khanal,2009:96).

Prithvi Narayan Shah (1722-1775) ascended the throne of Gorkha on $3^{\text {rd }}$ April,1743 at the age of 20 (Stiller, 2017:93). When he became the king, Nepal was a conglomeration of different principalities and kingdoms, each sovereign and autonomous in its own sphere. There were 22 kingdoms like Jajarkot, Jumla, Salyan, etc. on Karnali zone popularly known as Baise rajya and 24 kingdoms including Palpa, Tanahun, Kaski, Lamjung and Gorkha in Gandaki region known as Chaubise Rajya. Besides these, there were Sen kingdoms in the east known as Koshi Region whereas Malla Kingdoms in the Kathmandu Valley known as 'The Nepal Valley' and the areas surrounding it (Gautam,2074 B.S.). The Kathmandu valley itself was divided into three separate kingdoms of Kantipur, Bhadgaon and Patan. Relation between these separate political units were not always peaceful; family feuds and rivalries would usually draw neighboring kingdoms into hostilities and frequent battles among them for annexation. The number of states changed very often. When Prithvi Narayan Shah commenced his campaign of conquest and unification, he had to contend with more than a hundred rajas, most of whom ruled territories that were at least 
as large as Gorkha and roughly comparable to it in material and human resources (Joshi and Rose, 1966:4). At the same time, the British East India company was conquering India and planning to occupy Nepal for the extension of their trade with Tibet through Nepalese territory.

On the one hand, the Baise rajyas, Chaubise rajyas, Malla and Sen kingdoms were more powerful than Gorkha and were standing as the major challenge for the survival of the country. On the other hand, threats posed by the newly emerging dominant power in the Northern India, the British East India company, and a slowly but steadily expanding Chinese presence in Tibet (Rose, 1971: Xiii) was equally challenging for the existence of the country. In such conditions, it was really a difficult task for a small and economically weak country to preserve the sovereignty and territorial integrity of the country.

All the above internal and external factors were challenging the arrival of Prithvi Narayan Shah on the throne of Gorkha. Without any delay, after becoming the king, he conducted unification campaign and got victory upon Nuwakot and concluded his principal part of dream that is victory over Kathmandu Valley on 1769. After this victory he visited back to Nuwakot and breathed his last there in 1775. Prior to his demise in January 1775, he delivered golden instructions in the form of a text called Dibya Upadesh. This text was given from his death bed to his successors and citizens of Nepal to educate the countrymen about his difficult journey of unification.

However, it is stated that these counsels were given when Prithvi Narayan Shah moved his capital from Nuwakot at the last of his life. He summoned his priests, teachers, household (Thar Ghar; Pandey, Arjyal, Pantha, Rana, Khanal and Bohora), family nobles and his tutors (Gautam, 2074 B.S: 70). The instruction explains 
Prithvi Narayan Shah's accomplishment of the unification campaign. It also deals with the geopolitical vulnerability of his newly unified country and provided direction to the governing elite on how to pursue governance, nationalism and diplomacy to ensure the survival and security of Nepal from external threats (Adhikari, 2015). Although it is not clear about the date of publication of his instruction, the work of Dibya Upadesh was edited by Yogi Naraharinath in 1959 (2016 B.S.) in NepaliDevanagari script and translated by Ludwing Stiller in English in 1968. In such a situation, the questions automatically arise that what diplomatic insights are found in Dibya Upadesh? How far his diplomacy become useful to preserve the sovereignty and integrity of the country? And to what extent Dibya Upadesh provides guidelines to present day Nepalese diplomacy? The article attempts to address the above questions.

\section{Objectives and Methodology}

The article fundamentally looks at the diplomatic insights of Prithvi Narayan Shah expressed in Dibya Upadesh in shaping the position of Nepal in relation to its immediate neighbours and outside world. In addition, the specific objectives are to highlight the diplomatic insights found in Dibya Upadesh, to assess Prithvi Narayan Shah's diplomacy in relation to the preservation of the sovereignty and integrity of the country and to explore the relevancy of Dibya Upadesh in providing guidelines to Nepalese diplomacy.

Diplomacy today is a subject of vital importance. Because of sound diplomacy, Prithvi Narayan Shah was able to conduct unification campaign along with the preservation of national identity. Basically, guidelines of ruling to his successors and countrymen in the form of Dibya Upadesh are more important even in present day diplomatic dealing. Despite its significance 
in reframing diplomatic practices which can be employed in affecting policies of small states, and leadership of Prithvi Narayan Shah and his role in mediating the domestic politics and external policies, this text has been "too little known and too little appreciated" (Stiller, 1968: iii). The paper makes a brief description and analysis of Dibya Upadesh from diplomatic point of view. So, it is designed as both descriptive and analytical study. The required data like books, journals, official documents, newspapers and previous works are obtained from secondary sources and most of them are qualitative in nature.

\section{Literature Review}

Dibya Upadesh is taken as an original concept coined by Prithvi Narayan Shah, the founder of modern Nepal, thinking about the security, prosperity and development of the nation. After getting victory over Kathmandu Valley, he went to Nuwakot in 1774. He summoned the major stake holders and delivered his suggestions as guidelines for successful running of the country in the days to come. Dibya Upadesh, the teachings of Prithvi Narayan Shah, was delivered by him at the death bed to his successors and citizens of Nepal to educate them about his journey in the unification of Nepal. It was also hoped that the countrymen should follow this duty to ensure security and survival of Nepal.

He was in hope to transfer such suggestions from generation to generation. His spirit reads "when an old man dies, his words die with him, so they say. What you who are gathered here will hear from me, pass on to your children, and they to ours; and this kingdom will endure" (Stiller, 1968:38).

These suggestions later were taken as Dibya Upadesh(Divine Counsels). Though the authentic publication of this text is still unknown, but was edited by Yogi Naraharinath in 2016 B.S. 
(Acharya \& Yogi,2061 B.S.) and further edited and published by His Majesty the Government, Ministry of Youth, Sports and Culture, Department of Archaeology in 2054 BS (Dibya Upadesh,2054 B.S.). It presents the original text along with the explanation. All the above works were published in Nepali Devanagari script. Later, Ludwig Stiller translated it in English in 1968 (Stiller, 1968). Besides this, Stiller further highlighted the matter in his book The Rise of the House of Gorkha (Stiller, 2017). In addition to this, several other analysts have made researches in the subject. This is the basis on which Dibya Upadesh has been examined in this article.

\section{Level of Analysis}

Several theories have been developed in the analysis of diplomatic intercourse. All arguments and demonstration exhibited by the actor are measured using a level of analysis approach (Jackson and Sorensen, 2013:256). Hence, the personality, perception, choices and activity of individual decision maker have significant impact in diplomacy (Mingst, 2004:59). During early days of civilization, the role of individual was solely determined in conducting domestic and foreign affairs. It is relevant that it was Prithvi Narayan Shah's policy and not Nepal's in shaping diplomatic intercourse. Prithvi Narayan Shah, from the house of Gorkha, provided the vision and leadership that galvanized this state to concerted action and sustained it to the moment of victory (Stiller, 2017:94). He is considered as the successful person of his time and his campaign of unification was successfully conducted. His teachings are still relevant in the conduction of foreign policy and diplomacy as well which are his original innovation. So, the individual level analysis of diplomacy is particularly significant because of weight and capability of personality and authoritarian heritage in policy 
making and diplomatic dealings.

\section{Theoretical Framework}

The life of Prithvi Narayan Shah was full of struggle, strife and war. He started his career as the master of House of Gorkha at the age of 20 and continuously devoted his strength in the unification. Power (Hard Power) remained the central focus of his reign. His relation with Baise, Chaubise, Malla and Sen Kingdoms remained in hostility. Though some times he concluded treaties with some states as tactics, his successors were guided to follow independent foreign policy through the adoption of defensive diplomacy (Baral, 2018:25-45). In this scenario, realism and liberalism, the principal theories of international relations can be applied in the study of Dibya Upadesh.

Among various theories of international relations, political realism is the most popular one. It views all diplomatic dealings in terms of power (Goldstein and Pevehouse, 2008:43). Groupism, anarchism, egoism and power politics are the major propositions of political realism (Donnelly, 2008: 150-182). The relations are conflictual and may always lead to war and relation is influenced by the value of national security and state survival (Wohlforth,2008:131-149). This theory further focuses that an individual is primarily selfish and power seeking. Prithvi Narayan Shah was a man of high ambition. Most of the time of his reign was motivated by war and attack. His rule was much more influenced by the philosophy of Machiavelli and Kautilya, noted realists of Western and Eastern civilization. He spent his whole life in war as Machiavelli suggested his Prince to be prepared for war. Gorkha was a small kingdom and comparatively weak than Baise and Chaubise states in terms of geography, economy, resources and military might as well. So, the security of the state was always at stake. 
According to Stiller, Prithvi Narayan Shah was a man of decision, he was also realist enough to recognize the complexity of the task he was undertaking (Stiller, 2017:99). War/ hostility was greatly applied in his diplomacy. He fought many battles in his journey of Nepal's Unification keeping cost-benefit analysis into mind (Shah, 2016:19). Army and people comprised the main part of Shah's state before and after unification. Application of both offensive and defensive realism which emerged in the 1990s as outgrowth of Waltz's neorealism (Wohlforth, 2008:131-149) can be found in his teaching. Even after the unification, Nepalese security was found under threat because of the presence of strong external powers that is British- India and Tibet (China).

Yet, there is another widely applied theory in international relations that is Political Liberalism. This theory focuses on international co-operation and institutional arrangement. The scholars are more optimistic about the possibility of change and improvement in contrast to the realist emphasis on the continuous and unchanging nature of the reality of international anarchy and the omnipresent prospects of war (Stein, 2008: 201-221). They see the rules of international relations as slowly, incrementally evolving through time and potentially becoming more and more peaceful. By keeping this fact into consideration, Prithvi Narayan Shah was found very effortful to have good relations with Baise, Chasubise and other states in the surrounding. Signing treaty with Lamjung, developing friendship with Kaski and Tanahun, maintaining cooperation with Hari Shah, the king of Jajarkot, treaty with Kantipur and Bhadgaon were some examples of developing cooperation with the rival powers. $\mathrm{He}$ also tried to improve relations with Tibet and East India Company by deputing and receiving representatives there (K.C., 2001: 44-46). But all these efforts were made only as tactics to make unification campaign every success. Dibya Upadesh also 
focuses on the maintenance of good relations with immediate neighbours by viewing the challenge upon security from them. So, his diplomacy and the instructions in Dibya Upadesh can be examined mainly from a realistic point of view.

\section{Dibya Upadesh as Diplomatic Guidelines}

Diplomacy is as old as the civilization of states. However, it could not be found matured in the past. In spite of its glorious history, there are very less evidences of Nepal's diplomatic intercourse. However, it was able to preserve its sovereignty and integrity through the adoption of adequate diplomacy in challenging modes of history. Ancient history tells that Sita, Buddha, Bhrikuti, Araniko and many other national dignitaries displayed their role in this field (Baral, 2018:143). But diplomacy could not be effective after the downfall of Lichhavi dynasty. The country gradually fragmented into tiny states and unhealthy competition among themselves weakened the diplomatic capacity of the country. The systemic ground for modern diplomacy was somehow provided by Prithvi Narayan Shah. The diplomatic ability exhibited during unification is really remarkable in the diplomatic history of Nepal. Jayraj Acharya, a renowned Nepali diplomat, has highlighted five main elements discernible in Prithvi Narayan Shah's policy. He states:

First is the unification itself, without which he saw that there was no security or independence of the mountain principalities in the face of the expanding British colonial power that was expanding in the Indian plain. The second element was his military buildup, for which he selected competent commanders who were able to make proper assessment of the situation and take the right steps at the right time. The third element of his policy was a cautious friendship with British-India and China. The fourth element 
of his policy was a balance between offensive and defensive approaches. And the fifth element of his national security or foreign policy was strengthening the national economy by various policy measures. (Acharya, 2014:9)

Prithvi Narayan Shah's guidelines in the form of Dibya Upadesh are found equally relevant even in post-unification era. The key sectors of diplomacy as suggested by him can be analyzed in the following sub-headings:

\section{Psychological Determination and National Unity}

National psychology plays an important role in diplomacy. The image of a proud and brave nation, that has withstood the test of times and remained independent throughout the history was possible because of morale of policy maker (Dahal, 2009: 19-43). Prithvi Narayan Shah was found strong enough in his dealing. Firstly, he had strong determination to be the king of Kathmandu valley. Dibya Upadesh states "When I reached to Chandragiri's top I asked, which is Nepal? They showed me saying "that is Bhadgaon, that is Patan and there lies Kathmandu." The thought came in my heart that if I might be the king of these three cities, why let it be so?" (Stiller, 1968:39). In the same manner, when Jay Prakash Malla made a counter reply of Prithvi Narayan Shah's plan to attack Kirtipur saying "when the raja of Gorkha comes to take my kingdom, I will destroy his kingdom in an instant." And the raja of Gorkha wrote "If I cannot crush him, then I am not Prithvi Narayan Shah, the son of Narbhupal Shah" (Stiller, 2017:99). These facts prove that he had strong determination in his mission.

He paid equal attention in the unity of nation. He said that the country is not his little painfully acquired kingdom but a garden of every sort of people. He further says that if everyone is alert, this will be a true Hindustan of four Jaat, greater and lesser, of the 
thirty-six classes (Acharya \& Yogi, 2061 B.S.:50). Highlighting Prithvi Narayan Shah's effort in the development of nationalism and national unity S.D. Muni writes;

The origin of Nepali nationalism has been traced to the days of Prithvi Narayan Shah. He brought about the territorial and political unification of the country and tried to create among its inhabitants a feeling of unity. However, his approach was limited to territorial and political components of nationalism. Its social, economic, cultural and intellectual planes were not even touched. Whatever this, "feeling of oneness" might be, it declined after Prithvi Narayan Shah and vanished altogether with the rise of the Ranas (Muni, 2016: 36).

But the present- day Nepal's world view is conditioned by the perception of enormous neighbours, China and India (Rose, 1971:15). It is needed to deal with high morale in course of interacting with our immediate neighbours and other actors of international community.

\section{Alliance Diplomacy}

Formation of alliances and counter alliances is one of the devices commonly used in diplomacy. It was really a difficult task to conduct unification campaign for a small country like Gorkha. Lamjung, an old enemy, was proximate to it and was the major challenge in Gorkha's campaign. Realizing this fact, Gorkha signed a treaty with Lamjung. This effort was made by Kalu Pandey in 1740 (Gautam, 2074 B.S.:35). It was committed in the treaty that Gorkha and Lamjung would be friends. Lamjung would not interfere in Gorkha's eastward expansion and Gorkha was also ready to assist Lamjung in its move towards Chaubise states. 
Prithvi Narayan Shah also made an additional effort to maintain warm relations with different states for making his unification campaign quite a success. He also brought Tahanun, Kaski and Palpa in his favor. During his visit to Banaras, he met Hari Shah, the king of Jajarkot and did dharmapattra (deed of trust). He also met the king of Palpa, Mukunda sen, in Butwal while returning from Banaras.

Prithvi Narayan Shah had keen desire to be the king of Kathmandu valley. So, maintaining relations with Malla Kings of Kathmandu valley was important. His diplomacy to bring Malla kings in his side became fruitful when he signed a treaty with Kantipur and Bhaktapur to develop trade and facilitate his unification campaign (Rose, 1971: 23-24). Gorkha was not involved in any formal alliance, it only tried to strengthen the relations. There were certain traditional groupings to which most of the hill principalities belonged. The alliance like Palpa Alliance, Lamjung Alliance, Bhirkot Alliance, Parbat Alliance, Pyuthan Alliance and Family Alliance were formed with the purpose of the protection of sovereignty and territorial integrity (K.C, 2001:20-21).

\section{Institutional Arrangement}

Diplomacy is as old as the civilization of state and human relation. But this subject remained unstructured and unsystematized for a long period of time. Traditionally, it was an exclusive matter of reigning king. For the first time, an organized and institutional office to conduct foreign relations was established in France in 1626 and Britain in 1782. The functioning of foreign affairs in China begun mainly since 1861 and India achieved its definite shape only after the independence in 1947 (Bhattarai, 2076 B.S.: 18-19).

Nepalese diplomacy prior to the formation of modern Nepal was 
neither organized nor systematized. Though Nepalese foreign affair is one of the oldest institutions in the world. However, it was only after Nepal's unification in 1769 under the reign of King Prithvi Narayan Shah, Nepal's foreign office called Jaisi Kotha, was established (Acharya, 2019: 518). He had very clear vision in foreign policy and diplomatic matters. Jaisi Kotha, which was looked upon by intellectuals and persons having good handwriting, was named after Bhanu Jaisi who was the first officer (Bhattarai, 2076 B.S.:19). He also suggested to assign the duty to particular officer to look after the foreign affairs of the country.

According to Prithvi Narayan Shah, Kalu Pandey's family should be made responsible to look after the foreign relation with Tibet and Shiva Ram Basnyat's family was given the responsibility to maintain the relation with the southern neighbours (Dibya Upadesh, 2054 B.S.:22). In this way, Munsi family was selected to look after the diplomacy and foreign relation of Nepal. Today, we have Ministry of Foreign Affairs as an institution to conduct Nepalese diplomacy.

\section{Economic Diplomacy}

Economic matter is a serious issue raised in Dibya Upadesh. When Prithvi Narayan Shah ascended to the throne of Gorkha, he made first attack upon Nuwakot (Gautam, 2074B.S.:39). The main reason behind it was economic interest as Nuwakot was the important trade route to trade with Tibet and it had fertile soil with moderate climate. In economic front, he was convienced of the significance of home products for the internal use and export of the local herbs abroad. In his words "send our herbs abroad and earn money. Bring money into the country. If the citizens are fat(wealthy), the state is strong"(Dibya Upadesh,2054B.S.:21). He further says that "people are the 
treasury of the king" (Dibya Upadesh,2054B.S.:21). Making proper use of available resources is essential to make the country wealthy. So, he suggested that "in a place where there are mines, even if there is a village there, move the village and work the mine" (Acharaya \& Yogi, 2061 B.S.:57). It is again important to give top priority to native products and local industry. Dibya Upadesh reads "forbid the use of foreign cloth (in Nepal). Show samples to those who know how to make our clothes. Teach them and begin to make clothing. If this is done, our money will not go abroad" (Acharaya and Yogi, 2061 B.S.:49). He also suggested to be aware with foreign traders. He said, "do not let the merchants of India come up from the border. If the merchant of India come to our country, they will leave the people poor (Stiller, 1968:43). Though economic globalization does not agree with this. Nevertheless, the small state should be very careful in the matter.

\section{Non-aligned Diplomacy}

Non-alignment is the major base of Nepalese foreign Policy. King Prithvi Narayan Shah, a great cognizant of the geo-strategic setting of Nepal, propounded the policy of non-alignment (Aryal, Subedi \& Thapa, 2011:14). He was fully aware about the geo-strategic reality of Nepal and had suggested his successors to adopt this policy. His 'Yam Theory' is still popular as the fundamental base of Nepalese Foreign Policy and diplomacy as well. According to Prithvi Narayan Shah, "this country is like a gourd between two rocks. Maintain a treaty of friendship with the emperor of China. Keep also a treaty of friendship with the emperor of southern sea (the company) (Stiller, 1968:42). He had suggested to be in high alert with the Britishers. But the succeeding rulers failed to follow this policy and Nepal involved in war with Tibet and British- India in 1792 and 1814 
respectively (Khanal, 2009:100). This resulted limiting national boundary.

\section{Defensive Diplomacy}

Defensive policy in diplomatic dealing is one of the original contributions made by Prithvi Narayan Shah. He was aware of the presence of powerful rulers in the neighbourhood. The king knew that the Britrish in India were a colonial power hungry with expansionist desires. China in the north was a sleeping giant, which Nepal would least want to disturb (Acharya, 2019:82). By recognizing the unique geographical location, he suggested to adopt defensive policy especially with the external powers. He says, "The southern emperor (British- India) has taken the plains. He has suppressed Hindustan. He will realize that if Hindustan unites, it will be difficult and so he will come seeking places for forts" (Dibya Upadesh, 2054 B.S.:19).

He was very clear in his advice that Nepal should not operate military initiatives against either of them. Its preparedness should only be for defensive wars. His popular saying "jai katak nagarnu, jhiki katak garnu (do not go to attacks but should retaliate if it was attacked) (Acharaya \& Yogi, 2061 B.S.: 45). Proximately, whom he recalls Kasim Khan attacking Makwanpur, whom he defeated with a limited army of 120 Khukuri clad warriors. Similarly, he also recalls Hardy Sahib coming to attack Sindhuligadhi with three or four companies (Adhikari, 2015). Not only did he defeat Hardy Sahib and his army but also took possession of their weapons that is flintlocks.

In this way, Prithvi Narayan Shah was offensive in relation to smaller principalities which he subjugated with liberal use of force and took a defensive position against the greater powers in the south and north (Acharya,2014:19). So, the successors are advised not to go down to the plains to fight. Better to withdraw 
to the hills to fight. Chure pass will be much used. It will be possible to collect arms and ammunitions for five to seven generations and Ganga will remain a line of defense (Stiller, 1968:42).

\section{Founder of National Security}

For the first time in the history of Nepal, Prithvi Narayan Shah introduced a comprehensive national security policy. After the unification of Nepal in the mid- $18^{\text {th }}$ century, his Dibya Upadesh was adopted as the foundation of national security policy. It has embraced geo-political and geo-strategic sensitivity of the nation to protect and preserve territorial integrity of Nepal, which has been the guiding principle of national security policy ever since.

The main challenge during that period was to protect the sovereignty and territorial integrity of the country. Basically, the document Dibya Upadesh indicates the need for a healthy fear of the British (Stiller, 1968:47) as the arrival of British- India was almost sure, which could threaten the security of the nation. His slogan "jai katak nagarnu, jhiki katak garnu" was a core mantra in protecting the national interest that Prithvi Narayan Shah had stated in his famous Dibya Upadesh (Acharaya, 2019:142). Further, Dibya Upadesh states that soldiers are the backbone of king's power. They should always be in warm up position. He also declared Marawat, a compensation for soldier's death paid to his family, to boost-up the morale of the soldiers (Dibya Upadesh, 2054B.S.:24). Army strengthening, economic wellbeing, social harmony and other administrative reforms remained other aspects of independence and survival.

\section{Border Security and Secrecy}

Border security is one of the important aspects of national security. It was more important for Prithvi Narayan Shah to 
be careful in the protection of the border of extended state. He suggested to build permanent fort in various places having geo-strategic importance like Shivapuri, Chandragiri and other places. He also suggested to place the cannon at the higher places of the fort (Dibya Upadesh, 2054 B.S.:19). Dibya Upadesh further says that an iron door should be built in the gaps of the mountains. Behind each door on a higher place, cannon should be set up and a band of five soldiers stationed at each place. If this is done there will be no opportunity for ambush, spying, routing destroying, sneaking, trouble making, murder or anything like this (Stiller, 1968:42-43). Nepalese have very bitter experience of trans-border crime, border encroachment, fake currency, human trafficking, terrorism and other crimes due to poor security in the border.

He paid equal attention to maintain the secrecy of the country from security point of view. It was seen that Christian missionaries were the first Westeners who came to visit Nepal in 1628 and had been resided in Kathmandu. But after the conquest, Prithvi Narayan Shah expelled the missionaries from Kathmandu in 1768. Father Giuseppe, amongst the expelled one, was accused of gruesome incident of Kirtipur, alleging that Prithvi Narayan Shah's men had slain the noses of their enemies during the conquest (Upadhaya, 2018:17). According to stiller, missionaries was expelled not because he hated Christianity or he feared the Christians would convert the Hindus in Nepal to their religion; the king did so in the apprehension that they would not be the conduits for the British colonial influence in Nepal (Quoted, Acharya, 2019:20).

Prithvi Narayan Shah was equally careful in maintaining secrecy of the state. Dibya Upadesh reads; "Muglan (India) is near. In that place there are singers and dancers, in rooms lined with 
paintings they forget themselves in melodies woven on the drum and sitar. There is pleasure in their melodies. But it drains your wealth (Stiller, 1968:46). He was in fear of the possibility of opening the secrecy. So, he suggested not to practice the ragas. He further adds that if they are needed for Holi, bring a few and send them back quickly. It is better to involve the Newar community and if anything is given to them, it remains inside our country. If this is done, our country will be well protected (Dibya Upadesh, 2054 B.S.:28).

\section{Respect to Public Opinion}

Public opinion is taken as an important determinant of foreign policy and diplomacy as well. It enhances the competitive capacity of the country. Prithvi Narayan Shah's suggestion was to respect the voice of the people. It is evident that Kalu Pandey was appointed as Kazi based on public opinion. He says;

I was wondered. But I was also pleased. He, with whom the people are pleased, he, it is who made kazi, so the shastras say. I consulted the wishes of the people and found that the people wanted him. If Kalu Pandey is made kazi, all the people will be pleased. I was advised. Then I looked to the Baise and Chaubise princes. And they told me that if Kalu Pandey were made kazi, the home and foreign policy would be strong. It was in my mind to make Biraj Bakheti kazi (Stiller. 1968:40).

Further, Dibya Upadesh thinks about the prosperity and happiness of the people and focused on sound domestic policy as the most required condition for successful diplomacy. Prithvi Narayan Shah was aware of the matter. First, he paid sincere attention to maintain unity within family members. As mentioned in Dibya Upadesh "our mothers were three. Of three bridal chambers we brothers came, avtars of Pandavas" (Acharya \& Yogi, 2061 B.S. 
30). He compared his brothers with brave, obedient and honest Pandav as mentioned in Mahabharat. Actually, his mothers were four in numbers but the eldest mother Chandraprabhawati was childless. In the same manner, his diplomacy of maintaining unity among courtiers is equally worthy to mention. He said,"now I made marriage bond between the Pandes and Basnyat. I made Pandey the shield (foreign policy) and Basnyat the sword (war minister) and prepared to ascend to Nepal" (Dibya Upadesh,2054 B. S.:16).

\section{Expert's Opinion in Diplomacy}

Conducting diplomatic dealing by taking expert's opinion is very common in present day diplomacy. Prithvi Narayan Shah was a very young man when the government came into his hands, but he possessed excellent advisors, learned to use their suggestions well (Stiller,2017:94). He consulted his maternal uncle, Udyot Sen, the prince of Palpa, on the problem. The later said in reply "Lamjung is a large vulture, Gorkha, a snake and Nepal, a frog. Evade the large vulture, then the snake will have the frog to eat (Stiller, 1968:40). It is evident that Lamjung was the old enemy of Gorkha and more powerful than it. So, it could be the obstacle for the unification. By realizing the fact, treaty was signed with Lamjung through Kalu Pandey. Similarly, Prithvi Narayan Shah took the advice from Bise Nargarchi and other people of Gorkha. Bhanu Jaisi, Kulananda Jaisi and other intellectuals were there in the place of Gorkha. His suggestion is to consult with excellent advisors in the administration of the state. We have many think tanks and personal advisors of the ruler.

\section{Conclusion}

The geo- strategic location of Nepal has great impact in the determination of its foreign policy and diplomacy. It has 
remained the pivotal element to provide guideline in diplomatic dealings since the early time of civilization. Nepal has always been cautious in its survival in every phases of history and it became possible to preserve its integrity only through the adoption of adequate diplomacy. Nepal's sovereignty remained in challenging mode when Nepalese failed to display its diplomatic efficiency. However, the foundation of Nepalese diplomacy is rooted in Dibya Upadesh which has been providing continuous guidelines and is equally practical in the $21^{\text {st }}$ century Nepalese diplomacy. It was possible for Prithvi Narayan Shah to make a strong and unified Nepal by conquering rival states stronger than Gorkha. His last gift to the people of Nepal is his Dibya Upadesh delivered in a series of discourses during the last moment of his life. The guidelines in the formation of alliance, economic diplomacy and dealing with immediate neighbors are more practical. The pragmatic view of defensive diplomacy, adoption of non-align foreign policy, national security and border security are equally relevant. The suggestion of taking expert's opinion in the ruling of state, strengthening domestic unity and maintaining social harmony are also the major aspects of diplomacy which are more realistic in preserving national dignity and achieving economic prosperity.

\section{References}

Acharya, B. \& Yogi, N. (ed.) (2061 B.S.). Badamaharajdhiraj Prithvi Narayan Shaha ko Dibya Upadesh, Kathmandu: Shreekrishna Acharya.

Acharya, J. (2014). Nepal's foreign policy: a reflection, Kathmandu: SOPAN MONTHLY.

Acharya, M. R. (2019). Nepal: world view, Vol.1, foreign policy, New Delhi: Adroit Publishers.

Adhikari, B. (2015). The dibya upadesh of Prithvi Narayan Shah retrieved from spotlightnepal.com 
Aryal, D., Subedi, R. P. \& Thapa, S. (2011). Diplomatic Dealings, Kathmandu: Swodesh Aryal, Jyoti Subedi and Uma Thapa.

Baral, B. N. (2018). Changing dynamics of Nepalese foreign policy: patterns and trends in Journal of Political Science, 19, 25-45.

Baral, B. N. (2018). An introduction to diplomacy, Pokhara: Fishtail Publication Pvt. Ltd.

Bhattarai, M. K. (2076 B.S.). Pararastra kaa paatra, Kathmandu: Kitab Publishers.

Dahal, R. K. (2018). The need of change in contemporary nepalese foreign policy in Journal of Political Science, $19,82-113$.

Dahal, R. K. (2009). Challenges in the formulation of foreign Policy for Nepal in Nepalese Foreign Policy at the crossroads. Edited by Sushil Raj Pandey and Pushpa Adhikari, Kathmandu: Sangam Institute.

Dibya Upadesh (2054 B.S.). His Majesty the Government, Ministry of Youth, Spot and Culture, Department of Archaeology.

Donnelly, J. (2008). The ethics of realism in The oxford handbook of international relations, edited by Christian Reus-Smit $\&$ Duncan Snidal, Oxford University Press.

Gautam, R. (2074 B.S.). Political history of Nepal, Kathmandu: Bhudipuran Prakashan.

Goldstein, J. S. and Jon C. P. (2009). International relations (Eighth Edition), Dorling Kindersley India Pvt.Ltd, PEARSON.

Jackson, R. \& Sorensen, G. (2013). Introduction to intentional relations: theories and approaches ( $5^{\text {th }}$ edition), New Delhi: Oxford University Press.

Joshi, B. L. \& Rose, Leo E. (1966). Democratic innovations in Nepal: a case study of political acculturation, Berkeley: 
University of California Press.

Khanal, R. (2009). Donor Community and Nepal's Foreign Policy in Nepalese Foreign Policy at the Crossroads. Edited by Sushil Raj Pandey and Pushpa Adhikari, Kathmandu: Sangam Institute.

Mingst, K. A. (2004). Essentials of international relations (Third Edition). New York: W.W. Norton \& Company.

Muni, S.D. (2016). Foreign policy of Nepal, New Delhi: Adroit Publishers.

Rose, Leo E. (1971). Nepal: strategy for survival. London: University of California Press.

Shah, S. K. (2016). Dibya Upadesh: lessons for small state's diplomacy (Unpublished dissertation), Delhi: Department of International Relations, Faculty of Social Sciences, South Asian University.

Sharma, J. (2006). Nepal: Struggle for Existence. Kathmandu: Comm INC ICT Private Limited.

Stein, A. A. (2008). Neoliberal institutionalism in The oxford handbook of international relations, edited by Christian Reus-Smit \& Duncan Snidal, Oxford University Press.

Stiller, L. F. (2017). The rise of the house of gorkha (revised edition), Kathmandu: Educational Publishing House.

Stiller, L. F. (1968). Prithvinarayan Shah in the light of dibya upadesh, Kathmandu: Himalaya Book Centre.

Upadhya, S. (2018). Nepal and the geostrategic rivalry between China and India, London: Routledge Taylor \& Francis Group.

Wohlforth, W. (2008). Realism in The oxford handbook of international relations, edited by Christian Reus-Smit \& Duncan Snidal, Oxford University Press. 